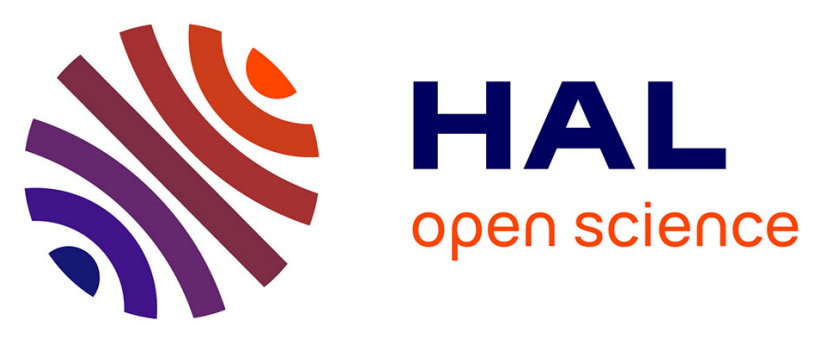

\title{
Reply concerning "Colchicine in coronary artery disease: Role of anti-inflammatory medications redefined": Prime time for anti-inflammatory agents for the management of cardiovascular diseases
}

\author{
Mariama Akodad, J. Fauconnier, Alain Lacampagne, François Roubille
}

\section{To cite this version:}

Mariama Akodad, J. Fauconnier, Alain Lacampagne, François Roubille. Reply concerning "Colchicine in coronary artery disease: Role of anti-inflammatory medications redefined": Prime time for antiinflammatory agents for the management of cardiovascular diseases. International Journal of Cardiology, 2018, 254, pp.52. 10.1016/j.ijcard.2017.12.059 . hal-01786608

\section{HAL Id: hal-01786608 \\ https://hal.umontpellier.fr/hal-01786608}

Submitted on 22 Dec 2019

HAL is a multi-disciplinary open access archive for the deposit and dissemination of scientific research documents, whether they are published or not. The documents may come from teaching and research institutions in France or abroad, or from public or private research centers.
L'archive ouverte pluridisciplinaire HAL, est destinée au dépôt et à la diffusion de documents scientifiques de niveau recherche, publiés ou non, émanant des établissements d'enseignement et de recherche français ou étrangers, des laboratoires publics ou privés. 


\title{
Reply concerning "Colchicine in coronary artery disease: Role of anti-inflammatory medications redefined": Prime time for anti-inflammatory agents for the management of cardiovascular diseases
}

\author{
Mariama Akodad $^{\mathrm{a}, \mathrm{b}}$, Jérémy Fauconnier ${ }^{\mathrm{b}}$, Alain Lacampagne ${ }^{\mathrm{b}}$, François Roubille ${ }^{\mathrm{a}, \mathrm{b}, *}$ \\ a PhyMedExp, University of Montpellier, INSERM U1046, CNRS UMR 9214, 34295 Montpellier cedex 5, France \\ b Cardiology Department, University Hospital of Montpellier, University of Montpellier, 34295 Montpellier cedex 5, France
}

Keywords:

Inflammation

Cardiovascular diseases

Colchicine

Canakinumab

Dear Dr. Ghosh, we appreciate your comments concerning our recently published manuscript "Interest of colchicine in the treatment of acute myocardial infarction responsible for heart failure in a mouse model."

Atherosclerosis is considered at least in part as an inflammatory condition [1] which is a main actor in cardiovascular disease.

Colchicine is a well-known anti-inflammatory drug with potential pleiotropic anti-inflammatory effects and has recently shown a benefit in acute myocardial infarction, decreasing the infarct size on MRI and creatine kinase peak [2]. These results were consistent with our mouse model of myocardial infarction [3].

These positive effects of anti-inflammatory drugs in cardiovascular disease seem to be available in clinical practice since the CANTOS study with a positive effect of canakinumab, a monoclonal antibody targeting interleukin $1-\beta[4]$.

Despite the recent failure of some promising drugs such as methotrexate (NCT01741558), trials are ongoing, evaluating the effect of various anti-inflammatory agents in percutaneous coronary interventions and in myocardial infarction, including small trials with everolimus (NCT01529554), rituximab (NCT03072199), and several evaluating tocilizumab (NCT03004703).

A dedicated international prospective randomized trial is currently ongoing, studying the effect of colchicine versus placebo on cardiac events after myocardial infarction within the last 30 days with an estimated study completion date in 2019 and an estimated enrollment of 4500 patients (NCT02551094). Using an unexpensive drug could offer a widely affordable way to promote this underestimated actor in cardiovascular diseases.

\section{Conflicts of interests}

The authors report no relationships that could be construed as a conflict of interest.

\section{References}

[1] G.K. Hansson, Inflammation, atherosclerosis, and coronary artery disease, N. Engl. J. Med. 352 (16) (2005) 1685-1695.

[2] S. Deftereos, G. Giannopoulos, C. Angelidis, et al., Anti-inflammatory treatment with colchicine in acute myocardial infarction: a pilot study, Circulation 132 (15) (2015) 1395-1403.

[3] M. Akodad, J. Fauconnier, P. Sicard, F. Huet, F. Blandel, A. Bourret, P. De Santa Barbara, Interest of colchicine in the treatment of acute myocardial infarct responsible for heart failure in a mouse model, Int. J. Cardiol. 240 (2017) 347-353.

[4] P.M. Ridker, B.M. Everett, T. Thuren, et al., CANTOS Trial Group, Antiinflammatory therapy with canakinumab for atherosclerotic disease, N. Engl. J. Med. 377 (2017) 1119-1131. 